\title{
STATUS OF THE WHITE-CLAWED CRAYFISH, AUSTROPOTAMOBIUS PALLIPES (LEREBOULLET, 1858), IN SPAIN : DISTRIBUTION AND LEGISLATION.
}

\author{
F. ALONSO (1), C. TEMIÑO (2) and J. DIÉGUEZ-URIBEONDO (3)*
}

(1) Centro de Investigación Agraria de Albadalejito, Junta de Comunidades de Castilla-La Mancha, Cuenca, Spain.

(2) Servicio Territorial de Medio Ambiente, Junta de Castilla y León, Burgos, Spain.

(3) Departamento de Patología Animal, Universidad de Zaragoza, Zaragoza, Spain.

* corresponding author / auteur pour correspondance

\begin{abstract}
The white-clawed crayfish, Austropotamobius pallipes, is the only native species of freshwater crayfish in Spain. This species sustained a first-magnitude inland fishery up to the end of 1970's, when the crayfish plague struck the Spanish waters.

It is detected an overall loss of distribution area of populations inhabiting the medium and lower reaches of the main river catchments, especially in Southern and Central Spain. The number of surviving populations can be estimated in ca. 700 . Remaining native crayfish populations currently inhabit marginal areas. The populations are very fragmented, occupy short stretches, and are frequently isolated from the main river system.
\end{abstract}

The current distribution is the result of a sum of different factors, i.e. crayfish plague, habitat alterations, extreme climatic drought, etc. The incidence and relative importance of each one varied during the last 15 years, with crayfish plague being a predominant negative factor in the seventies and eighties, and climatic drought in the nineties. The current trend of disappearance is a sufficient reason to consider the native crayfish as at risk of extinction. However neither the national legislation nor most of the regional government legislations have listed this species as endangered.

An analysis of the legislation dealing with freshwater crayfish in Spain shows : (a) an uneven and generally low level of protection given to the native species and (b) a very complex fishing and commercialization regulations for crayfish that show significant changes from one region to another. This complex legislation, complemented with a general lack of data on crayfish populations, low levels of management and public involvement, and different strategies in regional governments regarding restocking programs with exotic species, makes a confusing situation. 
In order to decrease the general tendency of regression of $A$. pallipes a conservation program for this species needs to be implemented in Spain. This program should include a number of regulations to be followed for the particular autonomous regions of Spain. This program should include measures : (a) to restore native crayfish populations, i.e. by translocations or stocking with farm raised of summerlings, in designated areas where the risk for crayfish plague outbreaks is low, (b) to control the spread of introduced species, by controlling their means of dispersal which usually occurs by human activities, i.e. trade of live crayfish, exotic crayfish stocking programs, crayfishing, aquaculture purposes, etc., and by developing eradication methods for unwanted crayfish populations ; (c) to increase the surveillance of remaining native populations by providing the areas with native crayfish the protection level required by the European Community Directives for the Conservation of Natural Habitats and Wild Flora and Fauna (92/43/EEC and 97/62/EU) ; and finally (d) to improve public and administration awareness.

\section{LA SITUATION DE L'ÉCREVISSE À PIEDS BLANCS, AUSTROPOTAMOBIUS PALLIPES (LEREBOULLET, 1858), EN ESPAGNE : RÉPARTITION ET LÉGISLATION.}

\section{RÉSUMÉ}

L'écrevisse à pieds blancs, Austropotamobius pallipes, est la seule espèce d'écrevisse autochtone en Espagne. Cette espèce a subi une pêche d'une grande envergure jusqu'à la fin des années 70 , quand la peste de l'écrevisse a ravagé les fleuves espagnols. Suite à cette maladie on assiste à une perte globale qui a particulièrement touché les populations du centre et du sud de l'Espagne, ainsi que celles situées dans les zones basses et moyennes des principaux bassins de son aire de répartition. Le nombre de populations subsistantes est estimé à environ 700. Ces populations d'écrevisses aútochtones occupent des zones marginales, sont très fragmentées, dans des tronçons de rivières très courts, et sont souvent isolées des fleuves principaux. En conséquence, on peut considérer qu'il existe un très haut risque de disparition, suite également à d'autres facteurs défavorables, en particulier l'effet des grandes sécheresses. Le rythme actuel de régression des écrevisses est une raison suffisante pour considérer que l'écrevisse autochtone est en danger d'extinction. Cependant, ni la législation nationale ni celle de la plupart des gouvernements régionaux place cette espèce parmi celles qui sont menacées.

L'analyse de la législation concernant les écrevisses met en avant : a) un niveau inégal et généralement faible de protection de l'espèce autochtone ; b) une réglementation fort complexe quant à la pêche et à la commercialisation des espèces allochtones qui n'obéissent pas aux mêmes règles selon la région. A cette législation complexe vient s'ajouter un manque général de données sur les populations d'écrevisses, de faibles niveaux de gestion et d'engagement public ainsi que des positions différentes de la part des administrations régionales sur les programmes d'introduction d'écrevisse signal, ce qui donne naissance à un panorama assez confus. Dans cet article, on se penche sur certaines lignes de gestion suivies dans la perspective de la conservation des populations autochtones et on signale les principaux besoins. C'est pourquoi on doit entreprendre des programmes coordonnés pour freiner la tendance générale régressive des peuplements, et l'on devrait développer un programme actif de conservation de l'espèce dans tout le pays. Ce programme devrait inclure des mesures pour restaurer les peuplements de l'écrevisse autochtone, pour contrôler l'expansion des espèces introduites, pour préserver et restaurer les habitats de cette écrevisse et pour augmenter ainsi la surveillance de ses peuplements, et ceci en impliquant les différents acteurs de l'environnement pour une conservation de l'espèce. 


\section{INTRODUCTION}

The white-clawed crayfish, Austropotamobius pallipes (Lereboullet, 1858) is native to Southern and Western Europe-(LAURENT, 1988) and is the only freshwater crayfish species native to the Iberian Peninsula. The distribution, abundance and habitat range of this species have been substantially reduced during the last decades (LAURENT, 1988). As a result, $A$. pallipes has been. placed on the Red List of Threatened Animals of the International Union for the Conservation of Nature and Natural Resources (I.U.C.N.) as a vulnerable species (BAILLIE and GROOMBRIDGE, 1996), and also in the Annexes $\|$ and IV of European Community Directives for the Conservation of Natural Habitats and Wild Flora and Fauna (92/43/EEC and 97/62/EU) as a species requiring special conservation measures.

Several factors are contributing to the regression of $A$. pallipes. Many of them are related to habitat alterations (LAURENT, 1988), but one of the main factors affecting native European freshwater crayfish is the crayfish plague. The crayfish plague is the most serious disease affecting freshwater crayfish and it has " wiped out " many populations of native crayfish in Europe. This disease is caused by the oomycetous fungus Aphanomyces astaci (UNESTAM, 1969), which is endemic to North America (UNESTAM, 1972 ; HUANG et al., 1994 ; DIÉGUEZ-URIBEONDO, 1995) and was probably introduced into Europe around 1860 (ALDERMAN and POLGLASE, 1988). It is known that at least three different strains of this fungus have been introduced into Europe during the last three decades by the stocking with North American crayfish, i.e. Orconectes limosus, Pacifastacus leniusculus, and Procambarus clarkii (P.ERSSON and SÖDERHÄLL, 1983 ; VEY et al., 1983 ; DIÉGUEZ -URIBEONDO and SÖDERHÄLL, 1993). These introductions gave raise to new epizootic events in native European crayfish populations (HUANG et al., 1994 ; LILLEY et al., 19907 ; VENNERSTRÖM et al., 1998 ;.OIDTMANN et al., 1997.; DIÉGUEZURIBEONDO and̆ TEMIÑO, 1998; ; DIÉGUEZ-URIBEONDO and SÖDERHÄLL, 2000).

A good example of the devastating effects of the plague is the abrupt regression of white-clawed crayfish in the Iberian Peninsula. Until the end of the 1970's, this species was widely distributed and very abundant throughout the waters of Spain and Portugal. Native crayfish fisheries represented a very important income for some local economies (MADOZ, 1850-1853 ; PARDO, 1942 ; MARGALEF, 1953 ; TORRE and RODRÍGUEZ, 1964). In the late 1970's a series of epizootic events occurred in Spain and the crayfish plague was determined to be the disease responsible for these massive mortalities (CUÉLLAR and COLL, 1983). These authors described how the plague spread to most of the waters bodies of Spain. Most crayfish populations disappeared in less than two years. As a result, the distribution of $A$. pallipes has been greatly reduced to headwaters and closed water bodies, in areas preserved from the threat of the crayfish plague and from human activities.

The decline of $A$. pallipes populations in the Iberian.Peninsula is probably ore the most abrupt ones: within the general tendency of regression for the European freshwater crayfish species. As a consequence the impact of this decline has been very important, not only economically: but also ecologically. This paper intends to review the current data about the distribution and legislation for $A$. pallipes and also to discuss the necessary steps required for preserving and restoring the native crayfish populations in Spain.

\section{DISTRIBUTION BEFORE THE PLAGUE}

Historical documents that have described the presence of A. pallipes in Spain are scarce if compared'with other freshwater species such as the Atlantic salmon, brown trout, barbel or eel (PARDO, :1950-1951). This makes it difficult to understand the original distribution of $A$. pallipes in Spain, since many translocations of crayfish have resulted in 
the expansion of its native range. The human influence on crayfish distribution in Spain was already pointed out by MARGALEF (1953). The first account of crayfish distribution was provided by MADOZ (1850-1853) and HUXLEY (1879). These accounts denoted the importance of crayfish fisheries in the local economies of rural areas in Spain. A similar description was given by PARDO (1942). This author described dense populations of crayfish from Ebro, Duero, Tajo, Júcar, Turia, Guadiana and other rivers of Spain (Figure1).

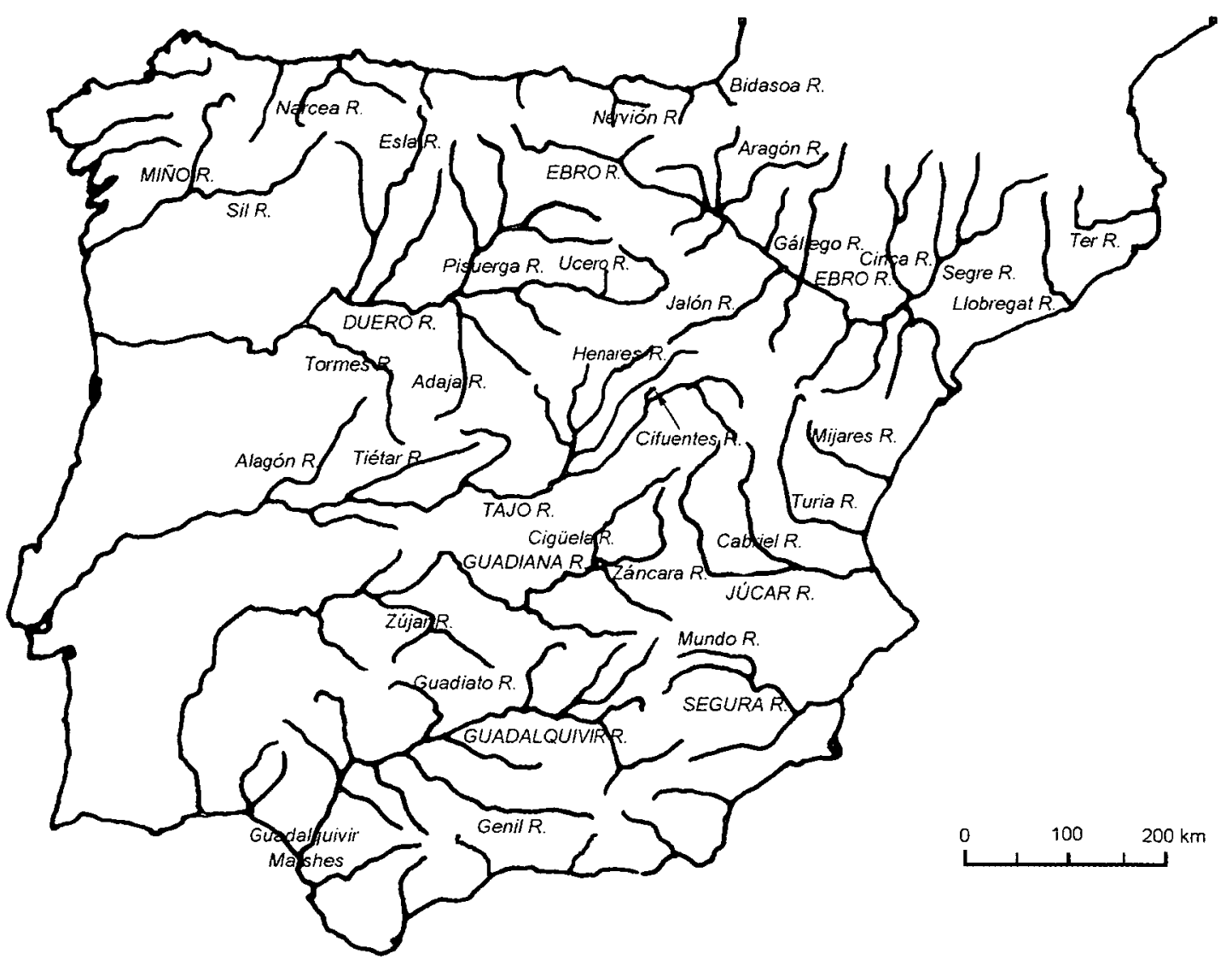

Figure 1

Hydrological map of Iberian Peninsula showing the main catchments.

Figure 1

Réseau hydrographique de la Péninsule lbérique présentant les principaux bassins.

TORRE and RODRÍGUEZ (1964) gave the most detailed report on crayfish distribution before the strike of the plague. These authors compiled a great amount of data on the crayfish distribution, density, catches and its marketing from most areas of Spain. They noted that the native crayfish was present in most calcareous areas and it reached the Mediterranean catchments in Granada, located in Eastern Andalucia (Figure 1), which represents the southern limit of the world distribution range of this species (LAURENT, 1988 ; GIL, 1999). The white-clawed crayfish was either absent or very rare in the acid rock outcrop areas, i.e. Galicia, Extremadura and West of Andalucia (Figure 2), and also in the arid areas of the South Eastern Spain, lower Ebro catchments, and the highest mountain ranges (Figures 1 and 3 ). 
Figure 2

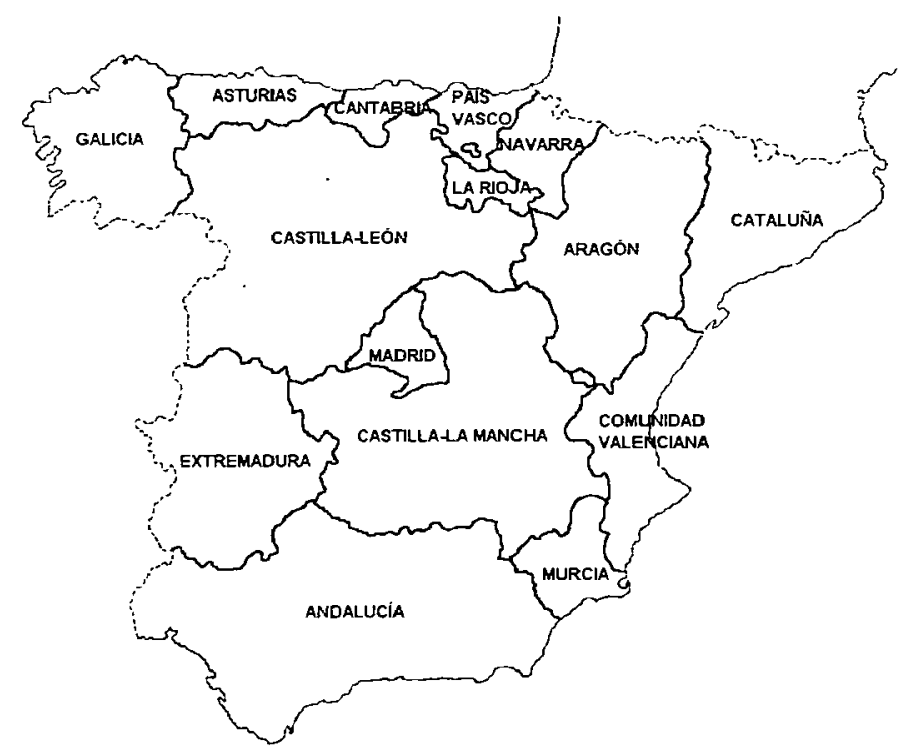

Political map of Peninsular Spain.

Figure 2

Carte politique de l'Espagne.

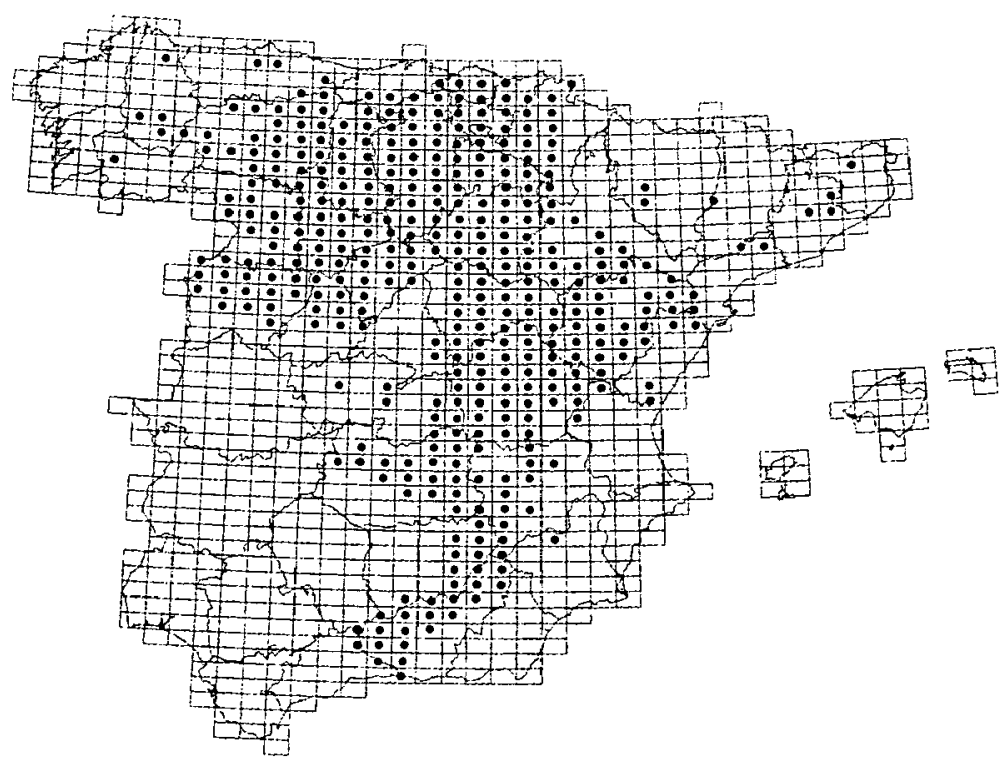

Figure 3

Distribution of the native crayfish Austropotamobius pallipes in Spain prior to crayfish plague spread, mostly following TORRE and RODRíGUEZ (1964). Black dots represent the presence of the species on a scale map from the National Geographic Institute 1:50000 grid.

\section{Figure 3}

Distribution de l'écrevisse autochtone Austropotamobius pallipes en Espagne avant la propagation de la peste. La plupart des renseignements ont été extraits de TORRE et RODRÍGUEZ (1964). Les points noirs signalent la présence de l'espèce. Carte, échelle 1:50000, de l'Institut National Géographique. 
Native crayfish were subjected to commercial fishing in many areas (PARDO, 1950-1951 ; TORRE and RODRÍGUEZ, 1964). From data on catches recorded by TORRE and RODRIGUEZ (1964), it is possible to estimate that in 1964 the annual yield of crayfish was at least of $2000 \mathrm{Tm}$. There were also crayfishermen guilds in some provinces (PARDO, 1950-1951), and crayfish were locally promoted as a delicacy. The relative importance of crayfishing within the overall inland recreational fishing activity in Spain can be also appreciated by studying the evolution of the number of total annual individual fishing rights (including both fish and crayfish). This number, which was rising steadily since the beginning of the century, dropped by nearly one third from 1978 to 1983 (ca 726.734 to, ca 515.349) (MUÑOZ, 1988), due to the decline of crayfish populations in that period. This shows the importance that $A$. pallipes had in Spanish fisheries, from an economical, social and recreational point of view.

\section{CURRENT DISTRIBUTION}

The impact of the plague in the seventies reduced the number of native crayfish populations dramatically in less than two years (CUÉLLAR and COLL, 1983). During the following years, the populations steadily decreased. TEMIÑO and SÁEZ-ROYUELA (1998) and ALDABE et al., (1991) estimated that the trend of native crayfish regression ranged from $30 \%$ to $50 \%$ every five years.

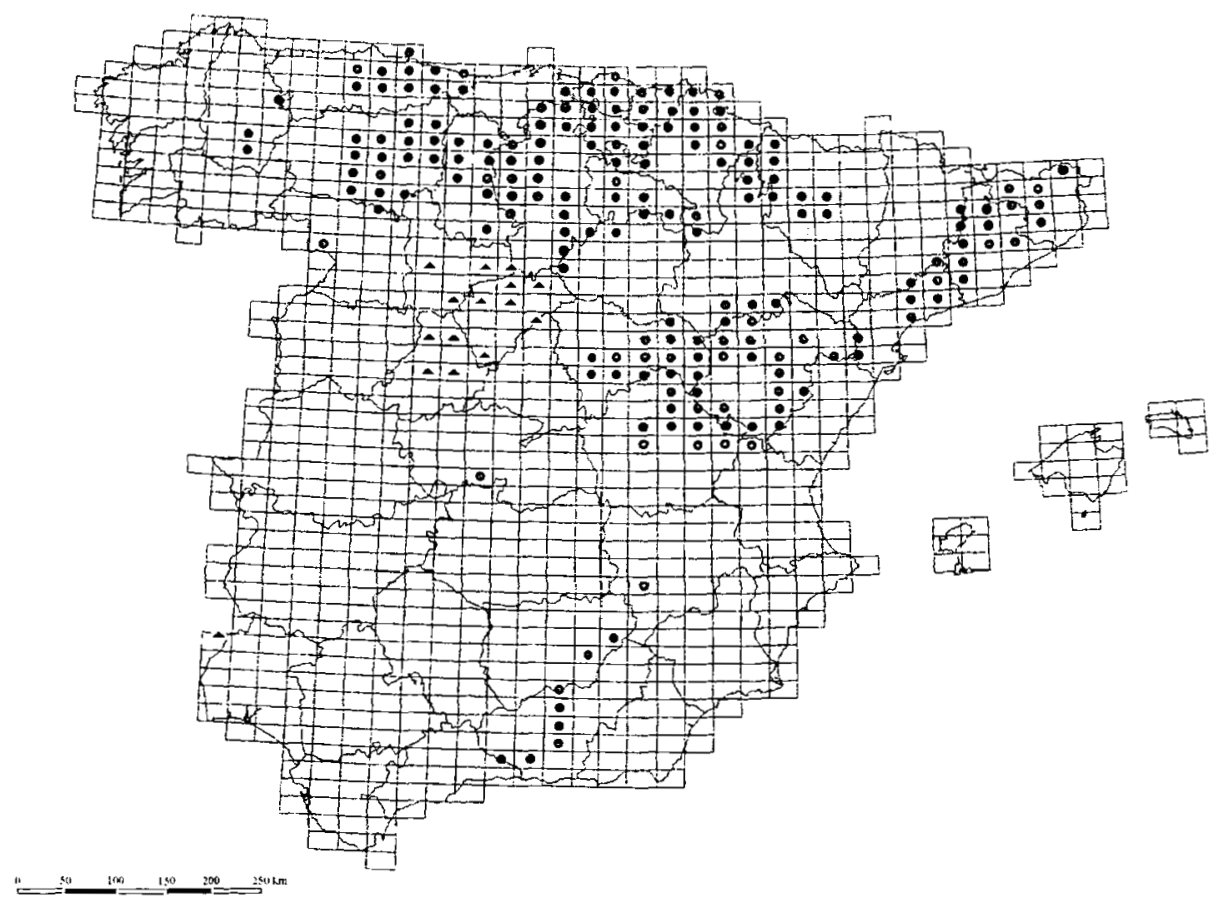

Figure 4

Present distribution of the native crayfish Austropotamobius pallipes in Spain. Black dots represent presence of the species on a map of the National Geographic Institute 1:50000 grid. Black triangles denotes data on presence on which we could not get information posterior to 1990.

\section{Figure 4}

Distribution actuelle de l'écrevisse autochtone Austropotamobius pallipes en Espagne. Les points noirs symbolisent la présence de l'espèce selon l'échelle 1:50000 de l'Institut National Géographique. Les triangles noirs montrent les niveaux de présence dont on n'a pas pu avoir d'informations après 1990. 
In order to understand the evolution of the populations of $A$. pallipes after the introduction of the crayfish plague several local distribution studies were undertaken in the regions of Andalucía (GIL and ALBA-TERCEDOR, 1998 ; GIL, 1999), Aragón (BOLEA, 1995), Asturias (DE LA HOZ, 1997), Castilla-León (CAMPOS and QUIROGA, 1988 ; GONZÁLEZ et al., 1989 ; MONDEDEU and ORTUÑO, 1989 ; LLAMAZARES and CELADA, 1990 ; GÓMEZ, 1991 ; LÓPEZ and GARRIDO, 1994 ; LEZÁRRAGA, 1995 ; PÉREZ-CECILIA et al., 1997 ; TEMIÑO and SÁEZ-ROYUELA, 1998), Castilla-La Mancha (LOZANO and MARTIN, 1988 ; ALONSO and MARTÍNEZ, 1998 ; ALONSO, unpublished), Cataluña (REY, 1994), País Vasco (GONZÁLEZ-TAPIA, 1986 ; GARCÍA-ARBERAS and RALLO, 2000 ; PINEDO, unpublished), La Rioja (MENDOZA and UNZU, 1997), and Navarra (AYERRA et al., 1986 ; ALDABE et al., 1991 ; DIÉGUEZ-URIBEONDO et al., 1997a ; DIÉGUEZ-URIBEONDO, 1999) (see Table I and Figure 4).

\section{Table I}

Actual number of populations of Austropotamobius pallipes in Spain and degree of surveying by regions.

\section{Tableau I}

Distribution actuelle des populations espagnoles d'Austropotamobius pallipes, et intensité de prospection par région.

\begin{tabular}{|c|c|c|}
\hline Region & Estimated number of populations & Regular surveys \\
\hline Andalucia & $\begin{array}{c}10 \\
\text { (Northern areas poorly prospected) }\end{array}$ & Some provinces \\
\hline Aragón & $\begin{array}{c}66 \\
\text { (data from 1993) }\end{array}$ & Yes \\
\hline Asturias & 48 & Yes \\
\hline Cantabria & $\begin{array}{c}\text { No information given at Fishery Department. Presence of } \\
\text { some populations suspected. }\end{array}$ & No \\
\hline Castilla-La Mancha & $50-70$ & Some provinces \\
\hline Castilla-León & $172-185$ & Some provinces \\
\hline Cataluña & (Data on 19 populations are from 1990 and before) & No \\
\hline Valencia & 90 & No \\
\hline Extremadura & (data from 1990) & No \\
\hline Galicia & $8-10$ & No \\
\hline La Rioja & Reported as absent & Yes \\
\hline Madrid & $10-20$ & No \\
\hline Murcia & 12 & No \\
\hline Navarra & No information available. Probably absent & Yes \\
\hline País Vasco & Not detected. Probably absent & - \\
\hline
\end{tabular}


By compiling the information contained in these distribution studies, it was possible to summarize the current distribution of $A$. pallipes in Spain (Figure 4). A notorious decline occurred in the populations in Central and Southern Spain. This decline is especially critical along the Guadiana and Guadalquivir catchments, and the middle reaches of Tajo, Duero and Ebro catchments (see Figures 1, 3 and 4). As a consequence, the main nucleus of populations is located in the Northern and Central Spain, with the southern populations being markedly isolated. Moreover, these studies showed that the number and size of the remaining populations have been drastically reduced, being now restricted to marginal habitats, i.e. headwaters or closed waters. Currently, the number of populations of $A$. pallipes can be estimated to be ca. 700 (Table I). However, some of the available data, i.e. part of Castilla-León and Cataluña, are nearly ten years old, and the actual number in these areas has most likely decreased. In contrast, other areas are poorly prospected, and may contain more populations. Interestingly, it can also be observed that A. pallipes is now present in some areas from where it was not reported by TORRE and RODRIGUEZ in 1964. In some cases, this is due to introductions by human, i.e. the dispersal of the species in Asturias and some parts of North Aragón (DE LA HOZ, 1997 ; BOLEA, 1995, respectively) (see Figures 2, 3 and 4). In other cases, the new records of $A$. pallipes along the Mediterranean catchments, especially in Cataluña and some parts of the Comunidad Valenciana, appear to be due to an incomplete information of the work of TORRE and RODRÍGUEZ (1964) (see Figures 1, 3 and 4).

\section{HABITAT CHARACTERIZATION}

The physic-chemical and morphological characteristics of the current habitat of the native crayfish were studied in several regions of Spain. The present distribution of A. pallipes retains most of the geographical distribution and also most of the original wide variation in physical-chemical characteristics of the water, with the exception of medium-sized and main rivers. Native crayfish now thrive in the marginal areas of its previous distribution range. Common features among most populations are that they live in first order streams, frequently isolated by summer drought from the main river system, and that they occupy less than ca $1 \mathrm{~km}$ of a stream (CELADA et al., 1985 ; GAUDIOSO et al., 1987 ; ALDABE et al., 1991 ; CARRAL et al., 1993 ; BOLEA, 1995 ; TEMIÑO and SÁEZ-ROYUELA, 1998).

TEMIÑO and SÁEZ-ROYUELA (1998) studied some selected morphological and physic-chemical characteristics and did not find remarkable differences between rivers harboring native crayfish populations and those in which the species had recently disappeared in the province of Burgos in Castilla-León. Thus, the data suggested that the current distribution of $A$. pallipes is mostly shaped by the spread of the crayfish plague (Table II).

The local density of $A$. pallipes can be occasionally high. ALONSO (unpublished) has calculated the biomass of $A$. pallipes in the streams of Castilla-La Mancha by studying over two years 13 points within three of the most important populations. It was found that the biomass of native crayfish ranged from $2.9 \pm 0.6 \mathrm{~g} \cdot \mathrm{m}^{-2}$ to $\mathrm{ca} 120.4 \pm 2.6 \mathrm{~g} \cdot \mathrm{m}^{-2}$. In these populations, hourly records of water temperature gave mean annual temperatures ranging from $8.8^{\circ} \mathrm{C}$ to $11.4^{\circ} \mathrm{C}$, and reaching absolute extreme values of $0.6^{\circ} \mathrm{C}$ and $24.0^{\circ} \mathrm{C}$, with a maximum daily oscillation of $10.5^{\circ} \mathrm{C}$. Less extreme values of temperature for $A$. pallipes populations were found by ALDABE et al. (1991) in the region of Navarra, where the temperature of the $A$. pallipes habitat ranges from the $9.3^{\circ} \mathrm{C}$ to $24.2^{\circ} \mathrm{C}$, with optimal values between $15^{\circ} \mathrm{C}$ and $18^{\circ} \mathrm{C}$. These authors also reported that populations of $A$. pallipes in Navarra live within the range of $240 \mathrm{~m}$ to $800 \mathrm{~m}$ above sea level, with most of them living within the 500-600 $\mathrm{m}$ range. ALONSO (unpublished) found that the remaining populations in Castilla-La Mancha presently live from $780 \mathrm{~m}$ to $1,520 \mathrm{~m}$ above sea level, which represents the highest altitude reported for this species. 


\section{Table II}

Some selected physico-chemical and morphological characteristics of rivers still harbouring native crayfish populations and comparison with rivers where the species recently disappeared in the province of Burgos. Data are taken from TEMIÑO and SÁEZ-ROYUELA (1998). Values are reported as mean (minimummaximum).

\section{Tableau II}

Quelques caractéristiques physico-chimiques et morphologiques des rivières hébergeant encore des populations d'écrevisse autochtone par rapport à celles où l'espèce a disparu récemment dans la province de Burgos. Les données sont issues de TEMIÑO and SÁEZ-ROYUELA (1998). Ci-dessous les résultats moyens (minimum-maximum).

\begin{tabular}{|l|c|c|}
\cline { 2 - 3 } \multicolumn{1}{c|}{} & $\begin{array}{c}\text { Rivers with native } \\
\text { crayfish populations }\end{array}$ & $\begin{array}{c}\text { Rivers without } \\
\text { native crayfish }\end{array}$ \\
\hline Number of rivers studied & 71 & 67 \\
\hline Total hardness (meq. $^{-1}$ ) & $5.6(1.1-7.9)$ & $5.9(2.5-9.0)$ \\
\hline Carbonate hardness $\left(\right.$ meq..$^{-1}$ ) & $4.5(1.1-6.8)$ & $4.4(1.4-6.1)$ \\
\hline pH & $7.5(6.5-8.5)$ & $7.6(7.0-8.5)$ \\
\hline Mean width $(\mathbf{m})$ & $0.9(0.3-1.5)$ & $0.8(0.3-2.0)$ \\
\hline Mean depth $(\mathbf{m})$ & $0.1(0.03-0.40)$ & $0.1(0.02-0.30)$ \\
\hline Length of stretch with crayfish $\mathbf{( m )}$ & $472(25-3000)$ & - \\
\hline
\end{tabular}

Regarding variations of $\mathrm{pH}, \mathrm{ALDABE}$ et al., (1991) reported a water $\mathrm{pH}$ range of 6.5 and 8.0, with an optimum around 7.0-7.5. These authors also observed that the mean depth ranged from 0.2 to $0.5 \mathrm{~m}$, and that crayfish preferred water courses with dense riparian vegetation and widths between 0.5 and $2.5 \mathrm{~m}$ (most of them in the $1.0 \mathrm{~m}-1.5 \mathrm{~m}$ range).

Finally, regarding water conductivity ALONSO (unpublished) found that $A$. pallipes populations of Castilla-La Mancha thrive in waters where the conductivity ranged between 450-900 $\mu \mathrm{S} . \mathrm{cm}^{-1}$. Interestingly, one population was found to live in water with a conductivity of only $50 \mu \mathrm{S} . \mathrm{cm}^{-1}$ similar to the values reported in Portugal by BERNARDO et al. (1997). In contrast, the highest conductivity value observed was $1,690 \mu \mathrm{S} . \mathrm{cm}^{-1}$.

\section{REASONS FOR CURRENT DECLINE}

CUÉLLAR and COLL (1983) determined that the epizootic events, which occurred in the late 1970's, were due to the crayfish plague. Even though they mentioned that previous massive mortalities were observed in the 1950's and 1960's, it seems unlikely that this episodes were due to crayfish plague (DIÉGUEZ-URIBEONDO et al., 1997b). It is now clear that the introduction of North American species of crayfish, i.e. P. clarkii and $P$. leniusculus, in the early 1970's constituted the way by which the fungus, $A$. astaci, was introduced into the Iberian Peninsula (DIÉGUEZ-URIBEONDO et al., 1997b). This is because all populations of North American crayfish studied in Spain have been found to be 
infected with the crayfish plague fungus and because they carry specific strains from their natural habitat in North America (DIÉGUEZ-URIBEONDO et al., 1995 ; DIÉGUEZURIBEONDO and TEMIÑO, 1998, DIÉGUEZ-URIBEONDO and SÖDERHÄLL, 2000). Since the crayfish plague fungus is an obligate parasite, which can only survive in freshwater crayfish species (CERENIUS and SÖDERHÄLL, 1992), these introductions have resulted in the establishment of chronic infected areas in the waters of Spain.

The initial loss of habitat range of the native crayfish was accelerated by the rapid attempts of fishermen and others, to restore crayfish populations by restocking with the North American crayfish, $P$. clarkii. The absence of adequate legislation for preventing the introduction of non-native species and the trade of living crayfish were factors that contributed to the rapid spread of $P$. clarkii. This same process is today being repeated with the signal crayfish, $P$. leniusculus, which is currently being used for restocking purposes.

On the other hand, other factors affecting native crayfish were overlooked due to the great magnitude of the initial crayfish plague outbreaks in Spain. It is known that other diseases (CERENIUS and SÖDERHÄLL, 1992 ; DIÉGUEZ-URIBEONDO et al., 1997b), and a number of different habitat alterations (TAUGBØL and SKURDAL, $1993 ; \mathrm{HOLDICH}$ and LOWERY, 1988) have a great impact on crayfish populations. These factors seem to have had a greater impact in Spain during the middle 1980's and the 1990's than during the 1970's and the early 1980's, since the native crayfish populations have progressively been restricted to marginal habitats, where they became more susceptible to habitat alterations such as climatic drought, organic pollution from farms, etc...

Several studies were conducted to identify and estimate the relative importance of factors involved in the loss of crayfish populations (TEMIÑO and SAEZ-ROYUELA, 1998 ; DIÉGUEZ-URIBEONDO et al., 1997b). TEMIÑO and SAEZ-ROYUELA (1998) studied the distribution and the causes of regression of $A$. pallipes populations in the province of Burgos in Castilla-Leon, during the period 1984-1997. This province is the most important in terms of number of populations and density of crayfish in Spain, both before and after the spread of crayfish plague (see Tables III and IV). They surveyed a total of 491 streams and ca 201 were found to harbor native crayfish populations at one time or another. In many cases, the reasons for crayfish disappearance could not be identified ( $45 \%$ of the cases) and were reported as populations disappearing for unknown reasons. Whenever it was possible to determine the cause of disappearance, climatic drought was found to be the most important factor (28\% of the cases). Climatic drought was especially severe in 1994, accounting for at least $50 \%$ of the population losses. Mass mortality episodes accounted for $17 \%$ of the population loss. Mass mortality episodes were especially important during the period 1984-1986, when they accounted for $45 \%$ of total population loss (TEMIÑO and SAEZ-ROYUELA, 1998). These episodes can sometimes be assessed as having a crayfish plague origin. DIÉGUEZ-URIBEONDO et al. (1997b) showed that crayfish plague was responsible for at least ca 7 out of 13 cases of mass mortalities studied during the last ten years in Spain and identified other factors responsible for mass mortalities such as saprolegniasis and pollution. TEMIÑO and SÀEZ-ROYUELA (1998) claimed that the real incidence of the crayfish plague is higher than the one deduced from the mass mortality data. They indicated that the progressive isolation of the native populations made it more difficult to detect these episodes, which were therefore reported as populations disappearing for unknown reasons. Consequently, their figures may underestimate the real incidence of the crayfish plague. Other factors involved in the disappearance of native crayfish populations were river canalization $(6 \%)$, water pollution ( $3 \%$ ), and poaching (1\%) (see Tables III and IV). 
Table III

Evolution of the number of native crayfish populations in the province of Burgos, during the period 1984-1997. Data are taken from TEMIÑO and SÁEZ-ROYUELA (1998).

Tableau III

Evolution du nombre de populations d'écrevisse autochtone dans la province de Burgos pendant la période 1984-1997. Les données sont issues de TEMIÑO and SÁEZ-ROYUELA (1998).

\begin{tabular}{|c|c|c|c|c|c|c|c|c|c|c|c|}
\cline { 2 - 13 } \multicolumn{1}{c|}{} & \multicolumn{10}{c|}{ Year } \\
\cline { 2 - 14 } & 1984 & 1985 & 1986 & 1988 & 1989 & 1990 & 1992 & 1993 & 1994 & 1995 & 1997 \\
\hline $\begin{array}{c}\text { A pallipes } \\
\text { presence confirmed }\end{array}$ & 60 & 74 & 42 & 71 & 17 & 34 & 6 & 71 & 74 & 74 & 66 \\
\hline $\begin{array}{c}\text { A.pallipes } \\
\text { presence probable }\end{array}$ & 1 & - & - & 13 & 2 & 13 & 1 & 6 & 8 & 16 & 27 \\
\hline $\begin{array}{c}\text { A.pallipes dissapeared } \\
\text { since previous year }\end{array}$ & 3 & 7 & 1 & 25 & $\mathbf{8}$ & 32 & 7 & 25 & 6 & 2 & 14 \\
\hline A. pallipes absent & 189 & 29 & 5 & 72 & 3 & 8 & 3 & 32 & 61 & 60 & 54 \\
\hline Total points sampled & $\mathbf{2 5 3}$ & $\mathbf{1 1 0}$ & $\mathbf{4 8}$ & $\mathbf{1 8 1}$ & $\mathbf{3 0}$ & $\mathbf{8 7}$ & $\mathbf{1 7}$ & $\mathbf{1 3 4}$ & $\mathbf{1 4 9}$ & $\mathbf{1 5 2}$ & $\mathbf{1 6 0}$ \\
\hline
\end{tabular}

Table IV

Analysis of the factors involved on loss of $A$. pallipes populations in the province of Burgos during the period 1984-1997. Data are taken from TEMIÑO and SÁEZROYUELA (1998).

Tableau IV

Analyse des facteurs qui ont contribué à la disparition des populations d'A. pallipes dans la province de Burgos pendant la période (1984-1997). Les données sont issues de TEMIÑO and SÁEZ-ROYUELA (1998).

\begin{tabular}{|c|c|c|c|c|c|c|c|c|c|c|c|c|c|c|c|c|}
\hline \multirow{3}{*}{ Causes } & \multicolumn{16}{|c|}{ Year } \\
\hline & \multicolumn{2}{|c|}{$1984-86$} & \multicolumn{2}{|c|}{1988} & \multicolumn{2}{|c|}{$1989-90$} & \multicolumn{2}{|c|}{$1992-93$} & \multicolumn{2}{|c|}{1994} & \multicolumn{2}{|c|}{1995} & \multicolumn{2}{|c|}{1997} & \multicolumn{2}{|c|}{ TOTAL } \\
\hline & $n$ & $\%$ & $n$ & $\%$ & $n$ & $\%$ & $\mathrm{n}$ & $\%$ & $n$ & $\%$ & $\mathrm{n}$ & $\%$ & $n$ & $\%$ & $\mathrm{n}$ & $\%$ \\
\hline Drought & - & 0 & 2 & 8 & 17 & 42 & 11 & 44 & 3 & 30 & - & 0 & 2 & 14 & 35 & 28.5 \\
\hline $\begin{array}{l}\text { Mass mortality of } \\
\text { unknown reason } \\
\text { crayfish plague } \\
\text { suspected) }\end{array}$ & 5 & 45 & 3 & 12 & 9 & 22 & 1 & 4 & - & 0 & - & 0 & 3 & 22 & 21 & .17 .1 \\
\hline Pollution & - & 0 & - & 0 & 2 & 5 & 1 & 4 & - & 0 & - & 0 & - & 0 & 3 & 2.4 \\
\hline Channelization & - & 0 & 1 & 4 & 1 & 3 & 2 & 8 & 1 & 17 & - & 0 & 1 & 7 & 6 & 4.9 \\
\hline Poaching & - & 0 & 1 & 4 & 1 & 3 & - & 0 & - & 0 & - & 0 & - & 0 & 2 & 1.6 \\
\hline Unknown & 6 & 55 & 18 & 72 & 10 & 25 & 10 & 40 & 2 & 33 & 2 & 100 & 8 & 57 & 56 & 45.5 \\
\hline Total & 11 & 100 & 25 & 100 & 40 & 100 & 25 & 100 & 6 & 100 & 2 & 100 & 14 & 100 & 123 & 100.0 \\
\hline
\end{tabular}




\section{INTRODUCTION OF EXOTIC SPECIES}

During the last fifty years, there have been several attempts to introduce other crayfish species into Spanish waters. The noble crayfish, Astacus astacus, is the first reported introduction of an exotic species into Spain. The noble crayfish was introduced in 1962. After successfully rearing the species for two years at two different hatcheries, some of the offspring were released into a nearby pond (GUTIÉRREZ-CALDERÓN, 1964). No further notice of its presence has been reported until today, so its introduction can be considered as a failure. The same can be said of Procambarus zonangulus, which was introduced in 1974 into the Guadalquivir marshes, simultaneously to $P$. clarkii (HABSBURGO-LORENA, 1979) and to Astacus leptodactylus, introduced for aquaculture purposes in 1975 in the province of Valladolid located in Castilla-Leon (HABSBURGOLORENA, 1979). Populations of naturalized Cherax destructor were found in ponds of Aragon (BOLEA, 1995) and Navarra (DIÉGUEZ-URIBEONDO, 1999). Orconectes limosus, which is very abundant in France (VIGNEUX, 1997, LAURENT, 1997) was found occasionally in Spanish markets (BOLEA, 1995), but fortunately has never been reported in the wild.

The red swamp crayfish, $P$. clarkii, and the signal crayfish, $P$. leniusculus, have widely dispersed from their original introduction areas. The introduction of the red swamp crayfish, which took place between 1973 and 1974 into Extremadura and Guadalquivir Marshes (see Figures 1 and 2), is particularly well documented (HABSBURGO-LORENA, $1979,1986)$. The species dispersed very quickly by human means, and in a few years appeared in distant areas such as the Albufera of Valencia in 1978, the Ebro delta, Zamora in Castilla-León in 1979, and currently only the province of Lugo in Galicia, is devoid of this species (CALLEJO, personal communication). Dense populations are found in most regions, primarily in Southern and Central Spain, i.e. Andalucía, Extremadura, Comunidad Valenciana, Castilla-La Mancha and Castilla-León (Figure 2), but also in areas of Duero and Ebro catchments. Industrial extensive exploitation takes place in some limited areas, especially the Guadalquivir marshes, where annual production averages from 2,900 to 3,500 Tm (GUTIÉRREZ-YURRITA, 1999).

Signal crayfish, $P$. leniusculus, was first introduced in 1974 and 1975 (HABSBURGO-LORENA, 1979) at two different hatcheries, respectively located in the Cifuentes River in the upper Tajo catchment, and the Ucero River in the upper Duero catchment (Figure 1). The spread of the species has followed a different pattern than the red swamp crayfish. The first wild populations were reported near the hatcheries in which they were introduced. This was followed by stocking-programs by local administrations, especially Navarra, País Vasco and Castilla-León (CARRAL et al., 1993 ; ALVAREZ et al., 1989 ; ALDABE et al, 1991, respectively). Currently, several populations of signal crayfish can be found in these regions, being locally abundant in the headwaters of the Duero and Ebro catchments. Signal crayfish is very scarce in Castilla-La Mancha (ca 7 populations), in Andalucía (ca 1 population) (GIL, personal communication), and in Comunidad Valenciana (ca 1 population) (URBANO, personal communication).

The progressive allowance to fishing signal crayfish in some areas since 1994, and the increasing demand for signal crayfish fisheries may allow a rapid spread of this species similar to the one experienced by $P$. clarkii. For example, after its introduction in 1986 at three localities in Cuenca province in the region of Castilla-La Mancha (LOZANO and MARTíN, 1988), no further spread of the species was observed until 1998, when a new isolated focus showing a well developed population was detected (ALONSO, unpublished). In the province of Burgos in the region of Castilla-Leon, the distribution of the species did not show substantial changes between 1984 and 1994, but it extend to new catchments since 1994, mostly likely due to the allowance to fish signal crayfish (TEMIÑO, 
unpublished). Moreover, the establishment of crayfish farms and intensive fishing facilities are responsible for the dispersal of the species, as new populations have been detected in the vicinity of crayfish farms, i.e. Cuenca (Castilla-la Mancha), Granada (Andalucia), Navarra, and Soria (Castilla-Leon).

\section{LEGISLATION}

The Spanish legislation relative to native crayfish conservation is complex. It includes nature conservancy legislation, inland fishing legislation and wildlife commerce legislation at both national and regional levels. Most of the regional governments have already issued their own regional acts concerning nature conservancy and inland fishing. However wildlife commerce legislation remains a national affair. Whenever regional legislation has not been developed, national regulations apply.

There are no references to regulations on crayfish catching in Spain before the National Fishing Act of 1907 (PARDO, 1950-1951; 1953). The fishing restrictions have changed several times during this century. At the beginning of the 1970's, a typical set of regulations for native crayfish catching included : a only legal way of fishing by net-trap, a minimum legal size of $8 \mathrm{~cm}$ postorbital length, a maximum number of eight baited lift nets per fisherman, and a limit of eight dozen crayfish per fisherman and day. Legal fishing season ran from April-May to September-October, depending on the areas considered, and an annual fishing-license was mandatory. Although it was erroneously reported elsewhere that $A$. pallipes can currently be fished in Spain, with annual catches reaching up to $5 \mathrm{Tm}$ per year (GUTIÉRREZ-YURRITA, 1999), in fact its fishing was forbidden throughout Spain since the beginning of the 1980's.

Regarding catching of naturalized exotic species of crayfish some specific fishing rules are issued each year for red swamp and signal crayfish, usually at a local level. Unfortunately, we often find different and contradictory rules even for nearby regions. For example, $P$. clarkii can be fished in most regions of Spain throughout the year, without size and number limitations, although a limit in the number of lift-nets is placed. Other regions, i.e. Pais Vasco, Navarra, and La Rioja, restrict catching to designated areas but without placing any other restrictions. Asturias and Castilla-La Mancha allows catching in designated areas with a temporal ban, while Castilla-León allows fishing under the same conditions, setting an ample catch limit of 20 dozen craytish. Murcia allows fishing throughout the year with a catch limit of 80 crayfish. Two Northern regions, i.e. Cantabria and Galicia have scarce populations of $P$. clarkii and do not allow catching for red swamp crayfish. Only in some areas of Andalucia, e.g. Guadalquivir marshes, there are sets of regulations devised for commercial fishing, including the use of crayfish traps.

In the last ten years, commercialization of live red crayfish has been subjected to a number of changes. National laws initially allowed at first commercialization of live animals of this species. In spite of that, Castilla-León succeeded in forbidding the commercialization of live crayfish for six years, supported by a decision of the Constitutional Court. However, this measure was abandoned in 1996, as a consequence of the pressure of fishmongers. They complained about the variable degrees of enforcement in each province. Interestingly, during that period the spread of $P$. clarkii in the province of Burgos was considerably slower than in surrounding areas, in which the ban was not strictly followed (TEMIÑO, unpublished). Cataluña, País Vasco and Navarra have banned live red swamp craytish commercialization in the last few years. As a result, a considerable decrease in the spread of $P$. clarkii has been observed in the region of Navarra (DIÉGUEZ-URIBEONDO and MUZQUIZ, 1999). However, in the rest of Spain, the red swamp crayfish can still be sold alive, and is readily available in local stores. 
Sale of $P$. leniusculus is not allowed by the National Legislation. This species is present in at least six regions and three of them, i.e. Castilla-León, Navarra and Pais Vasco, allow its catching. Catching is usually permitted in restricted places, with daily catch limits between 10 and 36 crayfish per fisherman, and with different legal sizes. In these three regions active stocking programs have been carried out since the late 1980's (ALVAREZ et al., 1989 ; CARRAL et al., 1993), and more introductions are being planned in Castilla-León (PÉREZ-CECILIA et al.,1997).

The traditional legislation concerning crayfish catching has been modified over the last few years with the aim of avoiding the dispersal of live crayfish by fishermen, following the example of the Scandinavian Legislations (SKURDAL and TAUGBØL, 1992). Thus, some regional legislations, i.e., Castilla-La Mancha, Cataluña, Navarra, require the killing in place of crayfish caught in the wild by taking out the telson. In Castilla-La Mancha, where national commercial laws allow the commerce of live $P$. clarkii, there is a contradictory situation : live crayfish can be purchased freely in the market alive, but should be killed when fished. Obviously, it is difficult to get these contradictory measures supported and adhered to fishermen. As the fishing laws included a disposition, which allowed live transportation in exceptional conditions, the actual degree of fulfillment of this measure in Castilla-La Mancha can be considered non-existent. Moreover in Pais Vasco and Navarra, the killing in place of the caught signal crayfish is not properly enforced. Moreover, another important aspect for preventing the spread of alien crayfish is the risk of using crayfish as live baits. We have not found any fishing regulations specifically addressing to it.

\section{Table V}

Additional protection measures on Austropotamobius pallipes in the regions where it is present. Protection levels are similar to those proposed by IUCN, except for Cataluña, which has developed its own protection criterions.

Tableau V

Mesures additionnelles de protection sur Austropotamobius pallipes dans les régions où l'espèce est présente. Les niveaux de protection sont semblables a ceux qui ont été établis par I'U.I.C.N., sauf pour la Catalogne, qui a développé ses propres critères de protection.

\begin{tabular}{|c|c|c|c|}
\hline Region & $\begin{array}{c}\text { Regional } \\
\text { Endangered } \\
\text { Species List }\end{array}$ & $\begin{array}{c}\text { Protection } \\
\text { Level given }\end{array}$ & $\begin{array}{c}\text { Restoration } \\
\text { Plan }\end{array}$ \\
\hline Navarra & Yes & Endangered & Yes \\
\hline La Rioja & Yes & Endangered & No \\
\hline Aragón & Yes & Vulnerable & No \\
\hline Castilla-La Mancha & Yes & Vulnerable & No \\
\hline Cataluña & Yes & Low sensibility & No \\
\hline Andalucia & Yes & None & No \\
\hline Asturias & Yes & None & No \\
\hline Comunidad Valenciana & Yes & None & No \\
\hline Madrid & Yes & None & No \\
\hline País Vasco & Yes & None & No \\
\hline Castilla-León & No & None & No \\
\hline Cantabria & No & None & No \\
\hline Galicia & No & None & \\
\hline
\end{tabular}


In spite of the native crayfish being at risk of extinction, the National Nature Conservancy Legislation (1989 Act) does not list $A$. pallipes, as endangered species. Most autonomous regional governments have issued their own Endangered Species Lists, but only five of them have listed the native crayfish as an endangered species and only two have given $A$. pallipes a protection level of endangered species (Table $V$ ). This is an important consideration because if a species is classified as endangered, a plan of restoration has to be implemented for it. Currently, only Navarra has developed a plan of restoration, which gives to the native crayfish the maximum level of protection trough classification of this species as at risk of extinction (DIÉGUEZ-URIBEONDO et al., 1997a). The plan is described in detail by DIÉGUEZ-URIBEONDO et al. (1997a), and includes measures relative to protection of native crayfish habitat range, and fisheries management, commerce and transport of exotic species. A similar plan was also implemented in Great Britain (HOLDICH et al., 1999). The plan of native crayfish restoration in Navarra delimits two exclusive areas, (a) a native crayfish area and (b) an alien crayfish area. Within the native crayfish area, transport and commerce of live crayfish is not allowed. In all cases crayfish should be killed after being fished. Red swamp craytish fishing is allowed only within the alien crayfish area, while signal crayfish fishing may take place, in some instances, within the native crayfish area. The plan also includes studies on the distribution and dynamics of the populations, health controls of crayfish, as well as actions to increase public awareness. In the rest of Spain, there has not been implemented any plan of restoration for the native species and this is surprising since the situation for most of the regions is more critical than in Navarra.

\section{DISCUSSION}

The regression of native crayfish populations throughout Europe results from a combination of negative factors. The Iberian Peninsula is probably the most severely affected areas. The current rate of nearly $50 \%$ population loss every five and the steady spread of North American species of craytish, are good reasons to consider the native crayfish species as at risk of extinction in Spain. The risks for native crayfish are very much the same throughout the country, and therefore an " endangered " $(\mathrm{E})$ category by IUCN should be adopted for this species. Unfortunately, the protection level given for this species in different regions is widely different (Table V), with the only exception of Navarra and La Rioja.

The differences in legislation mentioned above denote a lack of co-operation and co-ordination between regional fisheries and conservation authorities. Due to the present situation a joint effort needs to be carried out in order to decrease the tendency of the native crayfish populations loss. An common conservation program needs to be implemented throughout the country. This program should include measures that address at : (a) native crayfish populations restoration, (b) spread of introduced species, (c) habitat conservation and increases in surveillance of the native crayfish, and (d) public awareness and fishermen involvement in native crayfish conservatiōn.

\section{Restoration of native crayfish}

Populations of native craytish should be restored whenever possible, by means of reintroduction programs. The majority of water systems in Spain are opened, which makes them more vulnerable to the spread of epizootics than lacustrine systems. Therefore, restoration programs should take into account the particular characteristics of the water bodies to be restored. It is essential to evaluate the risk of transmission of crayfish plague by having an accurate knowledge of the distribution of exotic species in the area and their health status. Periodical surveys of distribution of both exotic and native species are needed in order to monitor the dynamics of populations and evaluate the risk of survival when establishing a new native population. Several studies with cage experiments have 
been helpful in evaluating this risk (SKURDAL and TAUGBøL, 1992 ; DIÉGUEZURIBEONDO et al., 1997a). Moreover, health status of crayfish used for restocking should be investigated in order to avoid the spread of parasites and pathogens (DIÉGUEZURIBEONDO et al., 1997a).

Presently, restoration programs are based exclusively on translocation of individuals obtained from natural populations and are limited by the low number and abundance of existing populations. Availability of individuals for restocking purposes needs to be substantially increased by either raising them at traditional hatcheries or in extensive ponds. The knowledge gained with other freshwater species, e.g. salmonids, on the problems relative to problems of stocking using hatchery-raised individuals should be taken into account (HINDAR et al., 1991 ; LEARY, 1991). Restocking activities have been carried out in Spain since the beginning of the 1980's. Castilla-La Mancha based its restoration effort in autumnal restocking with summerlings. The production followed the general procedure outlined by CUÉLLAR and COLL (1979) and COLL (1986). Current production of farmed native crayfish has decreased due to poor water quality (DIÉGUEZ-URIBEONDO et al., 1997b) at the El Chaparrillo farm located in Ciudad Real, which used to provide the highest production of native crayfish in Spain, with a maximum of 200,000 summerlings in 1994 (COLL, personal communication). In 1995-1998 and average of, 40,000 summerlings per year were stocked in Castilla-La Mancha (ALONSO and BEROIZ, 1998). As a result of this restocking program, several populations were established in the provinces of Cuenca and Guadalajara. In the province of Cuenca $35 \%$ of the populations originates from restocking. Translocations of native crayfish from natural populations to ponds were also successful in Pais Vasco and Navarra (PINEDO, personal communication ; DIÉGUEZ-URIBEONDO and MUZQUIZ, 1999, respectively). In these regions, $25 \%$ of the actual populations in Alava (Pais Vasco) and $10 \%$ in Navarra, originates from translocations of pond-raised crayfish.

In addition, the native stocking programs should take into account the genetic diversity of $A$. pallipes (SOUTY-GROSSET et al., 1997 ; GRANDJEAN et al. 1998), as most of the species genetic variability seems to be concentrated in the Mediterranean countries (SANTUCCl et al., 1997).

\section{Control of the spread of alien species}

The introduction of exotic species has a negative impact on the native species and it is important to emphasize the necessity of preventing the spread of introduced crayfish. Therefore, management of the exotic crayfish populations should inevitably be focused on controlling their means of dispersal, which usually occur by human activities. Special attention should be given to live commercialization, fisheries management and control and eradication measures. Control of crayfish dispersal by means of limiting their live commercialization is perhaps the most repeated advice issued by the scientific community for the control of introduced species (IAA, 1988) but has been rarely developed.

Today the most abundant species in the Iberian Peninsula is $P$. clarkii. This species has spread mainly by the trade of live crayfish. The contradictory regulations adopted by different local governments, still allows a further spread of this species. This red swamp crayfish is widely dispersed, especially in lower and medium reaches of main rivers. Stable populations of $P$. clarkii living over $1,000 \mathrm{~m}$ are uncommon, with a few exceptions for some lakes and reservoirs. It appears that parameters typical of riverine environments above this height, i.e. water temperature, slope, etc., may limit its distribution. In spite the fact that $P$. clarkii fishery represents an important industry in South Spain, this species is generally unwanted in most regions and some local governments have tried to eradicate it. These attempts have consisted basically on extending the legal catching season for $P$. clarkii throughout the year. However, these measures have had in most instances an opposite effect. In other cases, some local governments, i.e., Castilla-Leon, Navarra, Pais Vasco, 
have justified the introduction of the signal craytish, $P$. leniusculus, as a way to stopping the spread of the red swamp crayfish overlooking the main way of spread, the trade of live crayfish. Currently, the introduction of the signal crayfish constitutes one of the main topics regarding crayfish management. Several reasons have been given to justify the ongoing stocking programs of signal crayfish in Spain (GAUDIOSO et al., 1987). Firstly, the thought that stocking with this crayfish would to act as a " barrier " to prevent red swamp crayfish colonization of waters inhabited by the native species. Secondly, signal crayfish would fill an " ecological void " with an " ecological homologous " to native crayfish. Thirdly, colonization of waters by signal crayfish would to limit the eutrophication of water. Finally, signal crayfish would provide an alternative to the now vanishing opportunity of fishing.

Regarding these reasons, it has to be mentioned that : (a) the use of the term " ecological barrier" has been improperly used, i.e. Legislation of Navarra, and currently there is no scientific data describing the interaction and habitat segregation between $P$. leniusculus and $P$ clarkii. The purpose of using $P$. leniusculus as " ecological barrier ", contrasts with the repeatedly observed dispersal by man of signal crayfish outside the original stocking areas. With the spread of both signal and red swamp crayfish, several examples of coexistence in different environments are becoming available for studying their interaction. Subtle changes in population dynamics of each species, or a patch occupation of space can be expected, at least in an ample buffer zone, rather than the establishment of erroneously called «. absolute barriers ". Furthermore, the current scenario of mixed populations living together should be useful in predicting the future distribution of the crayfish species ; (b) regarding the much quoted statement of MASON (1977) on the ecological homology of signal crayfish to the native crayfish, it should be kept in mind that this statement is just a suggestion made in an abstract, and is not supported by specific data; (c) although several works have shown the effects of crayfish disappearance on macrophyte growth in lacustrine environments (ABRAHAMSSON, 1973 ; MATTHEWS et al., 1993 ; ELSER et al., 1994), the eutrophication derived from the absence of crayfish in riverine environments should be examined in detail. In Spain, organic effluents are treated only for $50.7 \%$ of the population census (MIMAM, 1999), and $70 \%$ of 1,181 control points placed in 310 rivers show some kind of pollution (AVILÉS et al., 1997). Thus, the construction or improvement of sewage facilities may prove a less risky, more effective and sensible way of controlling eutrophic conditions in rivers; and finally (d) without underestimating the positive impact on the local economy, that signal crayfish recreational fishery may have, it should be noted that the cost of signal crayfish stocking programs can be very high and usually competes with the limited funding available for the management and restoration of native populations. Moreover, the signal crayfish has been introduced in many water bodies suitable for restoring native crayfish and its fishery such as ponds and lakes. Consequently, further voluntary spread of signal crayfish by local governments overlooks the principles of humbleness, caution, and reversibility, which should guide these activities (MOYLE and MOYLE, 1995).

Finally, the use of fishing pressure as a way to control introduced species populations should be carefully addressed. Fishermen act as important agents for the dispersal of crayfish, especially in places, where there is a high demand for fishery development. Once an introduced species finds its way to a new area, managers face the dilemma of whether it is better to allow or forbid fishing, particularly when it is valuable. On one side, opening the fishery will result frequently in the spread of the species to other undesired areas, while on the other side it is difficult to explain to fishermen and the local public the reasons for not exploiting the populations. In this sense, it is important to develop and apply methods for eradicating populations (HOLDICH, 1999) as an alternative to this dilemma, even if they are not very efficient. It may be difficult to develop management techniques that allow control of the exploited populations and the best quality of fishery from the recreational point of view; but it should be attempted considering the current situation of expansion of exotic crayfish species in Spain. 


\section{Habitat conservation and surveillance}

Whenever possible areas occupied by native crayfish populations should be given protection in accordance to the European Community Directives for the Conservation of Natural Habitats and Wild Flora and Fauna (92/43/EEC and 97/62/EU). There is a need of information about the location and conditions of the current remaining native populations (Table I). Activities affecting areas harboring native crayfish populations, i.e. canalizations, water abstraction, chemical treatments in forest and agriculture, fish restocking, etc., should be subjected to environmental impact assessment evaluation. The great impact of climatic drought should be addressed specifically by avoiding water abstraction in native crayfish: areas, and by devising crayfish translocation programs. However, particular difficulties may arise when water is used for improve furthermore, the preservation of native populations should be based on increasing the surveillance of poaching and controlling selling points by a special policy.

\section{Public awareness}

Lack of information among fishermen and public administrations, and lack of involvement in conservation and recovery programs have negatively affected the situation of the native species. A great effort is needed to improve public awareness and management implication at all levels (TAUGBØL and SKURDAL, 1999). Information has been provided to the general public in a very limited way. A small number of leaflets on crayfish management and conservation have been issued up to date. Information programs must go further than leaflets, and should address different levels of knowledge, different motivations and different responsibilities. They should include, specifically, material devised to address each one of the groups of users or managers of the resources involved. A program within this framework is being drafted in Castilla-La Mancha and Navarra. Particular emphasis should be placed in increasing the concern for protection at all management and decision-making levels, including those in charge of wildlife management. For example, summer is a critical time of year during which many threats (e.g. poaching) or activities dealing with crayfish management (e.g. surveys) can take place. But during this season, the majority of the resources broadly assigned to wildlife management are diverted to similar areas of management, which receive greater media and public attention, in particular forest firefighting.

The involvement of local owners in the recovery of the fishery, especially from the economical point of view, remains a difficult task. Firstly, because promoting its economic value (TAUGBOL and SKURDAL, 1999) is difficult to achieve since the Spanish Legislation arises from ius romanum, so neither fishing-rights nor animals living in the waters belong to riverside owners. Freshwater animals are considered res nullius, e.g. belonging to nobody until being caught. Secondly, crayfish fishery was traditionally a valuable resource in Spain, and there is a demand to restore its fisheries. Currently the development of an incipient native crayfish fishery remains difficult due to the low number of populations and especially the lack of resources invested by the administrations. Nevertheless, the development of an incipient fishery is an important goal even if it is at a small scale.

Finally, the co-ordination of different conservation programs is one of the most difficult goals to achieve but is an essential factor for success. At a regional level, good co-ordination is needed between wildlife and fisheries managers, and water authorities and other management agencies, to avoid further population losses, especially those due to canalizations. An interregional committee such as the "Crayfish Plague Committee " established between Norway and Sweden (TAUGBØL and SKURDAL, 1999) would be highly desirable for the purpose of proposing general management guidelines and regulations in larger areas of the country. 
The few attempts made to restore native populations in Spain have had some success considering the little amount of resources invested and despite the great attention and support by the authorities that the exotic species have had, especially signal craytish. This paper intends to update the current situation of the native crayfish and emphasize the need for adapting the current legislation and actions to the risk of extinction of the white-clawed crayfish, $A$. pallipes, in the Iberian Peninsula.

\section{ACKNOWLEDGEMENTS}

The following persons provided invaluable information or advice on the current status of crayfish : populations in their respective regions : J. ALBA-TERCEDOR and J.M. GIL (Andalucia), J. DE LA HOZ (Asturias), J. LOZANO and J. MARTÍN (Castilla-La Mancha), J. CARRAL and E. ROY (Castilla-León), A. REY (Cataluña), J. GALINDO, J. JIMÉNEZ and J. URBANO (Comunidad Valenciana), F. ROLDÁN (Extremadura), A. CALLEJO (Galicia), I. TEJEDOR (La Rioja), J. GARCÍA (Murcia), and J. PINEDO and A. RALLO (País Vasco).

This work was supported by project INIA 96-SC-005 and Servicio de Investigación Agraria de Castilla-La Mancha, Servicio Territorial de Medio Ambiente de la Junta de Castilla y León en Burgos, and the Servicio de Medio Ambiente del Gobierno de Navarra and project $n^{\circ} 21817$ of the Gobierno de Aragon.

\section{REFERENCES}

ABRAHAMSSON S., 1973. The crayfish Astacus astacus in Sweden and the introduction of the American crayfish Pacifastacus leniusculus. Freshwater Crayfish, 1, 136-150.

ALDABE J., ESQUISABEL J.I., FERNANDEZ M.J., IRURZUN J.C., MENDIA F., RUEDA A., YOLDI B., 1991. Estudio de distribucion y abundancia de las species de cangrejos presentes en los rios navarros. Internal report of the Servicio de Medio Ambiente del Gobierno de Navarra, Pamplona, Spain.

ALDERMAN D.J., POLGLASE J., 1988. Pathogens, parasites and commensals. In : HOLDICH and LOWERY (Eds), Freshwater craytish : biology, management and exploitation, Croom Helm, London, 167-212.

ALONSO F., BEROIZ B., 1998. El cangrejo de río autóctono en Castilla-La Mancha. Medio Ambiente Castilla-La Mancha, 1, 23-25.

ALONSO F., MARTÍNEZ R., 1998. El cangrejo autóctono en Castilla-La Mancha : Problemática de conservación y recuperación. Trofeo Pesca, 69, 58-59.

ÁLVAREZ E., AUSÁN I., CABAÑAS C., 1989. Repoblación con cangrejo señal Pacifastacus leniusculus en los territorios de Alava, Vizcaya y Guipúzcoa. Internal report of the Departamento de Agricultura y Pesca del Gobierno Vasco, Vitoria, Spain.

AVILÉS J., TORO M., PEÑA R., 1997. Indicators of aquatic ecosystems quality in Spain. Eur. Aqua. Technical Review. Koblenz.

AYERRA J., CIRIZA F., ESQUISABEL J.I., IBARRA J., INSAUSTI J.A., 1986. Estudio de la distribución actual del cangrejo de río, Austropotamobius pallipes, en Navarra. Internal report of the Servicio de Medio Ambiente del Gobierno de Navarra, Pamplona, Spain.

BAILLIE J., GROOMBRIDGE B., 1996. IUCN Red List of Threatened Animals. IUCN, Gland, Switzerland.

BERNARDO J.M., ILHEU M., COSTA A.M., 1997. Distribution, population structure and conservation of Austropotamobius pallipes in Portugal. Bull: Fr. Pêche Piscic., 347, 617-624. 
BOLEA L., 1995. El cangrejo de río común en Aragón. Diputación General de Aragón, Zaragoza, $64 \mathrm{p}$.

CAMPOS F., QUIROGA R., 1988. Estudio para la ejecución del Plan Regional de conservación y fomento del cangrejo autóctono. Internal report of the Dirección General del Medio Natural de la Junta de Castilla y León, Valladolid, Spain.

CARRAL J.M., CELADA J., GONZALEZ J., SAEZ-ROYUELA M., GAUDIOSO V.R., FERNANDEZ R., LOPEZ-BAISSON C., 1993. Wild freshwater crayfish populations in Spain. Freshwater Crayfish, 9, 158-162.

CELADA J.D., GAUDIOSO V.R., CARRAL J., TEMIÑO C., FERNÁNDEZ R., 1985. Estado actual de las poblaciones y hábitats del cangrejo de río, Austropotamobius pallipes, (Lereboullet) en la provincia de León. An. Fac. Vet. León, 30, 179-194.

CERENIUS L., SÖDERHÄLL K., 1992. Crayfish diseases and crayfish as vectors for important diseases. Finnish Fisheries Research, 14, 125-133.

COLL M., 1986. Cultivo del cangrejo autóctono. In : GONZALEZ TAPIA J. (ed.), Jornadas de Estudio del Cangrejo de Río. Gobierno Vasco, Departamento de Agricultura y Pesca, Vitoria, 122-131.

CUÉLLAR L., COLL M., 1979. First essays of controlled breeding of Astacus pallipes (Ler.). Freshwater Crayfish, 4, 273-276.

CUÉLLAR L., COLL M., 1983. Epizootiology of the crayfish plague (Aphanomycosis) in Spain. Freshwater Crayfish, 5, 545-547.

DE LA HOZ J., 1997. Informe sobre la situación actual en Asturias de las poblaciones de cangrejo de río autóctono (Austropotamobius pallipes) y cangrejo americano de las marismas (Procambarus clarkii) con actualización de inventario de presencia. Internal report of the Consejería de Agricultura del Principado de Asturias, Oviedo, Spain.

DIÉGUEZ-URIBEONDO J., 1995. Adaptation to parasitism of some animal pathogenic Saprolegniaceae. Comprehensive Summaries of Uppsala Dissertations from the Faculty of Science and Technology, 112, 1-43.

DIÉGUEZ-URIBEONDO J., 1999. Plan de Recuperacion del cangrejo autotono en Navarra. Internal report of the Servicio de Medio Ambiente del Gobierno de Navarra, Pamplona, Spain.

DIÉGUEZ-URIBEONDO J., SÖDERHÄLL K., 1993. Procambarus clarkii Girard as a vector for the crayfish plague fungus, Aphanomyces astaci Schikora. Aquaculture and Fisheries Management, 24, 761-765.

DIÉGUEZ-URIBEONDO J., TEMIÑO C., 1998. Identificación de dos recientes brotes de la peste del cangrejo. Trofeo Pesca, 4, 68.

DIÉGUEZ-URIBEONDO J., MÚZQUIZ J.L., 1999. Plan de recuperación del cangrejo autóctono, Austropotamobius pallipes, en Navarra. Trofeo Pesca, 52, 76-78.

DIÉGUEZ-URIBEONDO J., SÖDERHÄLL K., 2000. RAPD Evidence for the origin of an outbreak of crayfish plague in Spain. Freshwater Crayfish, 12 (in press).

DIÉGUEZ-URIBEONDO J., HUANG T., CERENIUS L., SÖDERHÄLL K., 1995. Physiological adaptation of an Aphanomyces astaci strain isolated from the freshwater crayfish Procambarus clarkii. Mycological Research, 99, 574-578.

DIÉGUEZ-URIBEONDO J., RUEDA A., CASTIÉN E., BASCONES J.C., 1997a. A plan of restoration in Navarra for the native freshwater crayfish species of Spain, Austropotamobius pallipes. Bull. Fr. Pêche Piscic., 347, 625-637.

DIÉGUEZ-URIBEONDO J., TEMIÑO C., MUZQUIZ J.L., 1997b. The crayfish plague fungus in Spain. Bull. Fr. Pêche Piscic., 347, 753-763. 
ELSER J.J., JUNGE J., GOLDMAN C.R., 1994. Population structure and ecological effects of the craytish Pacifastacus leniusculus in Castle Lake, California. Great Basin Naturalist, 54(2), 162-169.

GARCIA-ARBERAS L, RALLO A., 2000. Survival of natural populations of Austropotamobius pallipes in rivers in Bizkaia, Basque country (North of Iberian Peninsula). Bull. Fr. Pêche Piscic., 356, 13-26.

GAUDIOSO V.R., CELADA J.D., CARRAL J., RODRIGUEZ P.L., 1987. El cangrejo de río en León. Universidad de León, León. $90 \mathrm{p}$.

GIL J.M., 1999. Situación, biología y conservación del cangrejo de rio autóctono (Austropotamobius pallipes) en la provincia de Granada. Doctoral Dissertation. University of Granada, Spain, $211 \mathrm{p}$.

GIL J.M., ALBA-TERCEDOR J., 1998. El cangrejo de río autóctono en la provincia de Granada. Quercus, 144, 14-15.

GÓMEZ M.S., 1991. Conservación y fomento del cangrejo autóctono de río en la provincia de Ávila. Internal report of the Servicio Territorial de Medio Ambiente de Ávila, Ávila, Spain.

GONZÁLEZ N., POLLO C.J., VELASCO J.C., LOSA J., 1989. Inventario astacícola de la provincia de Salamanca. Evolución y distribución de las poblaciones de cangrejo de río autóctono (Austropotamobius pallipes) y de cangrejo rojo americano (Procambarus clarkii). Internal report of the Servicio Territorial de Medio Ambiente de Salamanca, Salamanca, Spain.

GONZÁLEZ-TAPIA J.R., 1986. Estado de las poblaciones de cangrejo autoctono en Alava. In : GONZÁLEZ-TAPIA J.R. (ed:), Jornadas de Estudio del Cangrejo de Río. Gobierno Vasco. Departamento de Agricultura y Pesca, Vitoria, 122-131.

GRANDJEAN F., GOUIN N., FRELON M., SOUTY-GROSSET C., 1998. Genetic and morphological systematics studies on the crayfish Austropotamobius pallipes (Decapoda : Astacidae). Journal of Crustacean Biology, 18, 549-555.

GUTIÉRREZ-CALDERÓN E., 1964. Información sobre la aclimatación en España del cangrejo Edelkrebs. Boletín Técnico, Serie Piscícola. Ministerio de Agricultura, Madrid. $26 \mathrm{p}$.

GUTIÉRREZ-YURRITA P.J., MARTINEZ J.M., ILHEU M., BRAVO-UTRERA M.A., BERNARDO J.M., MONTES C., 1999. The status of crayfish populations in Spain and Portugal. In : GHERARDI F. and HOLDICH D.M. (Eds), Crayfish in Europe as alien species. How to make the best of a bad situation? Rotterdam (Balkema : Crustacean Issues, Vol II), 161-192.

HABSBURGO-LORENA A.S., 1979. Present situation of exotic species of crayfish introduced to Spanish continental waters. Freshwater Crayfish, 4, 175-184.

HABSBURGO-LORENA A.S., 1986. The status of the Procambarus clarkii populations in Spain. Freshwater Crayfish, 6, 131-133.

HINDAR K., RYMAN N., UTTER F.M., 1991. Genetic effects of cultured fish on natural fish populations. Can. J. Fish. Aquat. Sci., 48, 945-957.

HOLDICH D.M., LOWERY R.S., 1988. Freshwater crayfish-biology, management and exploitation. Croom-Helm, London. 498 p.

HOLDICH D.M., ROGERS W.D., REYNOLDS J.D., 1999. Native and alien crayfish in the British Isles. In : GHERARDI F. and HOLDICH D.M. (Eds.), Crayfish in Europe as alien species. How to make the best of a bad situation? Rotterdam (Balkema : Crustacean Issues, Vol II), 221-235.

HUANG T., CERENIUS L., SÖDERHÄLL K., 1994. Analysis of genetic diversity in the crayfish plague fungus, Aphanomyces astaci, by random amplification of polymorphic DNA. Aquaculture, 126, 1-10. 
HUXLEY T.H., 1879. The crayfish. An introduction to the study of zoology. Kegan Pau, I, London. 371 p. (4 ${ }^{\text {th }}$ Edition published by The MIT Press, Massachusetts).

I.A.A. (INTERNATIONAL ASSOCIATION OF ASTACOLOGY), 1988. Resolution of the International Association of Astacology. Freshwater Crayfish, 7, xxxvi.

LAURENT P.J., 1988. Austropotamobius pallipes and A. torrentium, with observations on their interaction with other species in Europe. In : HOLDICH D.M. and LOWERY R.S. (Eds), Freshwater crayfish : biology, management and exploitation. Croom-Helm, London, 341-364.

LAURENT P.J., 1997. Introductions d'écrevisses en France et dans le monde, historique et conséquences. Bull. Fr. Pêche Piscic., 344/345, 345-356.

LEARY R.F., 1991. Why not stock? In : STOLTZ J. and SCHNELL J. (Eds), Trout. Stackpole Books, Harrisburg, 346-350.

LEZÁRRAGA M., 1995. Informe sobre los cangrejos en la provincia de Zamora. Internal report of the Servicio Territorial de Medio Ambiente de Zamora, Zamora, Spain.

LILLEY J., CERENIUS L., SÖDERHÄLL K., 1997. RAPD evidence for the origin of the crayfish plague outbreaks in Britain. Aquaculture, 157, 181-185.

LLAMAZARES T.E., CELADA J.D., 1990. El cangrejo de río en la provincia de León. Inventario 1989. Internal report of the Servicio Territorial de Medio Ambiente de León, León, Spain.

LÓPEZ M.A., GARRIDO G., 1994. Revisión y ampliación del inventario de cangrejos en aguas continentales de Soria. Internal report of the Servicio Territorial de Medio Ambiente de Soria, Soria, Spain.

LOZANO J., MARTIN J., 1988. Trabajos de investigación sobre acuicultura y gestión en la provincia de Cuenca. In : JCCM y DIPUTACIÓN DE CUENCA (Eds), I Jornadas de Acuicultura en Castilla-La Mancha.Cuenca, 155-197.

MADOZ P., 1850-1853. Diccionario geográfico-estadístico-histórico de España y sus posesiones de Ultramar. Madrid.

MARGALEF R., 1953. Los crustáceos de las aguas continentales ibéricas. Ministerio de Agricultura, Madrid. $243 p$.

MASON J.C., 1977. Reproductive efficiency of Pacifastacus leniusculus (Dana) in culture. Freshwater Crayfish, 3, 101-117.

MATTHEWS W.A., REYNOLDS J.D., KEATING M.J., 1993. Macrophyte reduction and benthic community alteration by the crayfish Austropotamobius pallipes. Freshwater Crayfish, 9, 289-299.

MENDOZA F., UNZU F.J., 1997. Informe sobre las poblaciones de cangrejo autóctono en la Comunidad Autónoma de La Rioja. Internal report of the Servicio de Protección de Fauna Silvestre de La Rioja, Logroño, Spain.

MIMAM (MINISTERIO DE MEDIO AMBIENTE), 1999. Actuaciones públicas en materia de Medio Ambiente. Secretaría General Técnica. Madrid, Spain.

MONDEDEU I., ORTUÑO S., 1989. Estudio sobre la conservación y el fomento del cangrejo autóctono. Segovia. Internal report of the Servicio Territorial de Medio Ambiente de Segovia, Segovia, Spain.

MOYLE P.B., MOYLE P.R., 1995. Endangered fishes and economics : intergenerational obligations. Environmental Biology of Fishes, 43, 29-37.

MUÑOZ G., 1988. Crónica piscicola continental hispana. ICONA, Serie Técnica. Ministerio de Agricultura, Pesca y Alimentación, Madrid. 193 p.

OIDTMANN B., CERENIUS L., SCHMID I., HOFFMANN R., SÖDERHÄLL K., 1997. Crayfish plague epizootics in Germany - classification of two German isolates of the crayfish plague fungus Aphanomyces astaci by random amplification of polymorphic DNA. Diseases of Aquatic Organisms, 35, 235-238. 
PARDO L., 1942. Astacicultura elemental. Ministerio de Agricultura, Madrid. 174 p.

PARDO L., 1950-1951. Apuntes para la historia de la pesca continental española. Instituto Forestal de Investigaciones y Experiencias, Madrid. $342+448$ p. (2 vols.)

PARDO L., 1953. Apuntes para la historia del Servicio Piscícola. Tomo I : Parte General. Instituto Forestal de Investigaciones y Experiencias, Madrid. $346 \mathrm{p}$.

PÉREZ-CECILIA P., CASTRO E., GONZÁLEZ J.C., 1997. Inventario de cangrejo autóctono en la provincia de Palencia. Internal report of the Servicio Territorial de Medio Ambiente de Palencia, Palencia, Spain.

PERSSON M., SÖDERHÄLL K., 1983. Pacifastacus leniusculus Dana and its resistance to the parasitic fungus Aphanomyces astaci Schikora. Freshwater Crayfish, 5, 292-298.

REY A., 1994. El cranc de riu a Catalunya. Internal report of the Dirección de Agricultura, Ramadería i Pesca. Girona, Spain.

SANTUCCI F., IACONELLI M., ANDREAN! P., CIANCHI R., NASCETTI G., BULLINI L., 1997. Allozyme diversity of European crayfish of the genus Austropotamobius. Bull. Fr. Pêche Piscic., 347, 663-676.

SKURDAL J., TAUGBØL T., 1992. Crayfish management in Norway. Finnish Fisheries Research, 14, 33-37.

SOUTY-GROSSET C., GRANDJEAN F., RAIMOND R., FRELON M., DEBENEST C., BRAMARD M., 1997. Conservation genetics of the white-clawed crayfish Austropotamobius pallipes: the usefulness of the mitochondrial DNA marker. Bull. Fr. Pêche Piscic., 347, 677-692.

TAUGBØL T., SKURDAL J., 1993. Noble crayfish catching in Norway : legislation and yield. Freshwater Crayfish, 9, 134-143.

TAUGBøL T., SKURDAL J., 1999. The future of native crayfish in Europe : how to make the best of a bad situation? In : GHERARDI F. and HOLDICH D.M. (Eds), Crayfish in Europe as alien species. How to make the best of a bad situation? Rotterdam (Balkema : Crustacean Issues, Vol II), 271-279.

TEMIÑO C., SÁEZ-ROYUELA C., 1998. Resumen de los inventarios de cangrejo autóctono Austropotamobius pallipes realizados en la provincia de Burgos entre 1984 y 1997. Internal report of the Servicio Territorial de Medio Ambiente de Burgos, Burgos, Spain.

TORRE M., RODRÍGUEZ P., 1964. El cangrejo de río en España. Servicio Nacional de Pesca Fluvial y Caza, Ministerio de Agricultura, Madrid. 107 p.

UNESTAM T., 1969. On the adaptation of Aphanomyces astaci as a parasite. Physiologia Plantarum, 22, 221-235.

UNESTAM T., 1972. On the host range and origin of the crayfish plague fungus. Rep. inst. Freshw. Res. Drottningholm, 52, 192-198.

VENNERSTRÖM P., SÖDERHÄLL K., CERENIUS L., 1998. The origin of two crayfish plague (Aphanomyces astaci) epizootics in Finland on noble crayfish, Astacus astacus. Ann. Zool. Fennici, 35, 43-46.

VEY A., SÖDERHÄLL K., AJAXON R., 1983. Susceptibility of Orconectes limosus Raff. to the crayfish plague, Aphanomyces astaci Schikora. Freshwater Crayfish, 5, 284-291.

VIGNEUX E., 1997. Les introductions de crustacés décapodes d'eau douce en France. Peut-on parler de gestion? Bull. Fr. Pêche Piscic., 344/345, 357-370. 